\title{
Assessment of Wind Energy Potential as a Power Generation Source in Five Locations of South Western Nigeria
}

\author{
Nnawuike Nze-Esiaga, Emmanuel C. Okogbue \\ Department of Meteorology, Federal University of Technology, Akure, Nigeria \\ Email: nnawuike@gmail.com, emokogbue@gmail.com
}

Received 26 February 2014; revised 26 March 2014; accepted 3 April 2014

Copyright (C) 2014 by authors and Scientific Research Publishing Inc.

This work is licensed under the Creative Commons Attribution International License (CC BY). http://creativecommons.org/licenses/by/4.0/

(c) (i) Open Access

\begin{abstract}
In this study, the wind speed characteristics and energy potential in five selected locations in the southwestern part of Nigeria were investigated using monthly mean wind speed data of 51 years obtained from the Nigeria Meteorological Agency. The data were subjected to the 2-parameterWeibull and other statistical analyses. The outcome showed that the wind speed measured at a height of $10 \mathrm{~m}$ ranged from 1.3 to $13.2 \mathrm{~m} / \mathrm{s}$ while the modal wind speed ranges from 3.0 to $5.9 \mathrm{~m} / \mathrm{s}$. $83.6 \%$ of the data were found to be greater than $3.0 \mathrm{~m} / \mathrm{s}$. The average monthly wind speed ranged from 2.72 to $7.72 \mathrm{~m} / \mathrm{s}$. Seasonally, average wind speeds ranged between 3.47 to $6.55 \mathrm{~m} / \mathrm{s}$ and 3.83 to $6.94 \mathrm{~m} / \mathrm{s}$ for dry (October to March) and wet (April to September) seasons, respectively. The two parameters of the Weibull statistics were found to lie between $2.99 \leq \mathrm{k} \leq 5.32$ and $3.02 \leq \mathrm{c} \leq$ 8.57 , respectively. The annual mean power densities are $65.09,145.07,176.96,387.07$ and 87.34 $\mathrm{W} / \mathrm{m}^{2}$ for Abeokuta, Akure, Ibadan, Ikeja and Oshogbo respectively. It was further shown that the respective mean annual values of the most probable wind speed are 3.82, 4.97, 5.23, 7.03 and 4.01 $\mathrm{m} / \mathrm{s}$, while the annual values of the wind speed carrying maximum energy are $4.12,5.48,5.87,7.50$ and $4.55 \mathrm{~m} / \mathrm{s}$. These results indicate that wind speed has the viable potential for wind-to-electricity at height of $10 \mathrm{~m}$ for most of the locations assessed but it will be more viable in all the stations at a height above $10 \mathrm{~m}$.
\end{abstract}

\section{Keywords}

Wind Power, Wind Speed, Weibull Parameters, Southwestern Nigeria

\section{Introduction}

The concern over the production of adequate and sustainable electricity to drive economic developments is a

How to cite this paper: Nze-Esiaga, N. and Okogbue, E.C. (2014) Assessment of Wind Energy Potential as a Power Generation Source in Five Locations of South Western Nigeria. Journal of Power and Energy Engineering, 2, 1-13.

http://dx.doi.org/10.4236/ipee.2014.25001 
global issue. Although the conventional sources of fossil fuel burning have been able to produce surplus amount of energy, its finite nature is a concern for the future. Employing environment friendly and non-toxic sources for energy production has gained wide acceptance across the globe. This is because these sources which include wind, solar and hydro are non-depletable and so contain sustained potentials for abundant energy generation. This has led to various efforts at measuring and assessing their potentials for electricity generation. Wind Energy Technology (WET) application involves three important stages of resource assessment, hardware development and installation, and also electricity generation and distribution [1]. The first stage, which in this case is the potential resource assessment and the objective of this study is very important to the other two stages and therefore to WET.

Many studies have been carried out on wind resource assessment around the world to determine the potentialities of local sites for wind power/electricity [2]-[9]. Also, several studies on wind resource assessment have been done in Nigeria [10]-[18]. Each one of these reports considered different sites and presented analyses to justify their results. ECN-UNDP (2005) reported that due to the varying topography and roughness of the nation, large differences in wind distribution within the same locality exist. This is corroborated by the fact that wind resources are site specific and despite reports summarizing for the country, a site-by-site assessment is necessary in order to have proper wind classification for the nation. This work is therefore a wind resource assessment of wind measuring sites in five major towns in the southwestern region of Nigeria. It assessed the wind energy resources of the sites to determine its monthly, yearly and seasonal potentials for electricity generation.

\section{Materials and Methods}

Fifty one years (1961-2011) monthly mean wind speed data employed for this study were obtained from the Nigeria Meteorological Agency (NIMET). The data were measured continuously using three cup generator anemometer at a height of $10 \mathrm{~m}$ above sea level. Table 1 presents information about the cities. The data were then analyzed to determine the monthly, seasonal and yearly wind resource potentials for power generation.

\section{Data Analyses}

The Weibull distribution has been found to be most adequate of the various statistical distributions that could be employed for describing and analyzing wind resource data. Moreover, the 2-parameters Weibull statistical distribution has been proved to be more accurate than that of the 3-parameters. It can be employed in describing and predicting the characteristics of prevailing wind profile over a place [18] [19]. This study therefore employed the 2-parameters Weibull Probability Density Function (PDF) with scale (c) and shape (k) being the parameters. The Probability Density Function $(f(v))$ and the corresponding Cumulative Density Function $(F(v))$ associated with the 2-parameter Weibull distribution are given by Equations (1) and (2) respectively [18]:

$$
\begin{gathered}
f(v)=\left(\frac{k}{c}\right)\left(\frac{v}{c}\right)^{k-1} \exp \left[-\left(\frac{v}{c}\right)^{k}\right] \\
F(v)=1-\exp \left[-\left(\frac{v}{c}\right)^{k}\right]
\end{gathered}
$$

where $f(v)=$ the probability of observing wind speed $v, k=$ the dimensionless Weibull shape parameter and $c(\mathrm{~m} / \mathrm{s})=$ the Weibull scale parameter.

Table 1. Details of the selected cities.

\begin{tabular}{ccccc}
\hline Station & Latitude $(\mathrm{N})$ & Longitude $(\mathrm{E})$ & Altitude $(\mathrm{m})$ & Air Density $\left(\mathrm{kg} \cdot \mathrm{m}^{-3}\right)$ \\
\hline ABEOKUTA & 7.10 & 3.20 & 104.00 & 1.21 \\
AKURE & 7.17 & 5.18 & 375.00 & 1.18 \\
IBADAN & 7.26 & 3.54 & 227.20 & 1.20 \\
IKEJA & 6.35 & 3.20 & 39.40 & 1.22 \\
OSHOGBO & 7.47 & 4.29 & 302.00 & 1.19 \\
\hline
\end{tabular}


The wind power density $\left(\mathrm{W} / \mathrm{m}^{2}\right)$ which is the quantitative measure of the wind energy available at any location can be estimated from the Weibull parameters as [18]:

$$
p(v)=\frac{1}{2} \rho c^{3}\left(1+\frac{3}{k}\right)
$$

where $p(v)=$ wind power density, $\rho=$ air density.

The mean value of the wind speed, $v_{m}$, and standard deviation, $\sigma$, for the Weibull distribution is defined in terms of the Weibull parameters, $\mathrm{k}$ and c, as [4] [6] [18] [20]:

$$
\begin{gathered}
v_{m}=c \Gamma\left(1+\frac{1}{k}\right) \\
\sigma=\sqrt{c^{2}\left\{\Gamma\left(1+\frac{2}{k}\right)-\left[\Gamma\left(1+\frac{1}{k}\right)\right]^{2}\right\}}
\end{gathered}
$$

where $\Gamma(x)$ is the gamma function of $x$.

The evaluation of the most probable and maximum energy carrying wind speeds is very important to wind energy assessors. They can be evaluated from Equations (6) and (7) [18]:

$$
\begin{aligned}
v_{m p} & =c\left(\frac{k-1}{k}\right)^{\frac{1}{k}} \\
v_{E \max } & =c\left(\frac{k+2}{k}\right)^{\frac{1}{k}}
\end{aligned}
$$

where: $v_{m p}=$ most probable wind speed and $v_{E \max }=$ maximum energy carrying wind speed.

\section{Results and Discussions}

Analysis of the whole data spread revealed that the sites' wind speeds average ranged between 1.3 and $13.2 \mathrm{~m} / \mathrm{s}$ over the period of consideration. Figure 1 and Figure 2 however, present the average monthly and annual wind speed profiles respectively, covering the period between 1961 and 2011 for the five cities.

Figure 1 showed that the months with highest and lowest wind energy potential for Abeokuta occurred in April and November respectively, for Akure in March and October respectively, for Ibadan in April and November, for Ikeja in August and December, and for Oshogbo in March and November respectively. Figure 1 and Figure 2 also reveals that average wind speed values for the period lay between 3.2 and $4.3 \mathrm{~m} / \mathrm{s}$ for Abeokuta, 4.0 and $5.4 \mathrm{~m} / \mathrm{s}$ for Akure, 3.8 and $6.0 \mathrm{~m} / \mathrm{s}$ for Ibadan, 5.8 and $7.7 \mathrm{~m} / \mathrm{s}$ for Ikeja and 2.7 and $4.7 \mathrm{~m} / \mathrm{s}$ for Oshogbo for the period from January to December. The annual range lay between 2.0 and $5.7 \mathrm{~m} / \mathrm{s}$ for Abeokuta, 2.7 and $7.5 \mathrm{~m} / \mathrm{s}$ for Akure, 3.1 and 7.3 for Ibadan, 3.8 and $10.4 \mathrm{~m} / \mathrm{s}$ for Ikeja and between 2.0 and $6.2 \mathrm{~m} / \mathrm{s}$ for Oshogbo, thus showing that Ikeja has the highest range and Oshogbo having the lowest.

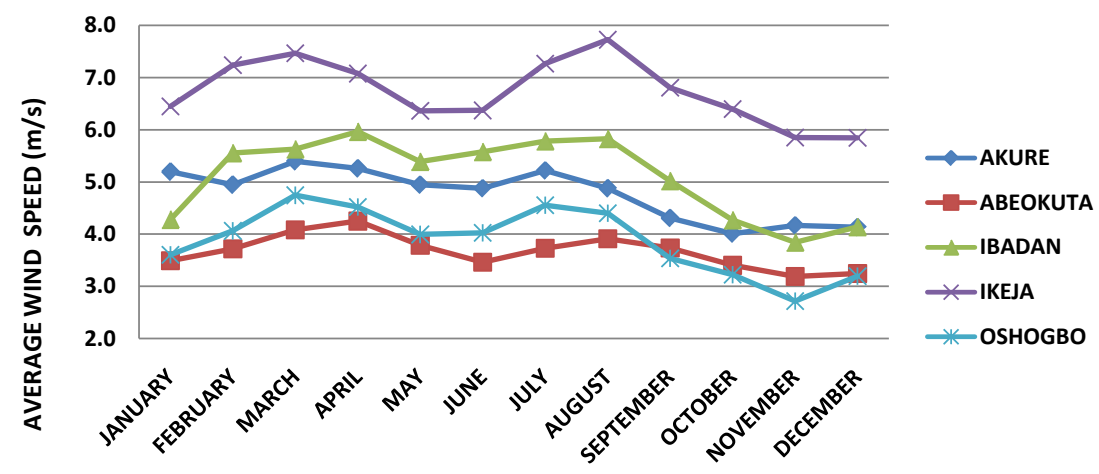

Figure 1. Monthly average wind speeds (at $10 \mathrm{~m}$ height) over Abeokuta, Akure, Ibadan, Ikeja and Oshogbo, Nigeria for the period 1961-2011. 


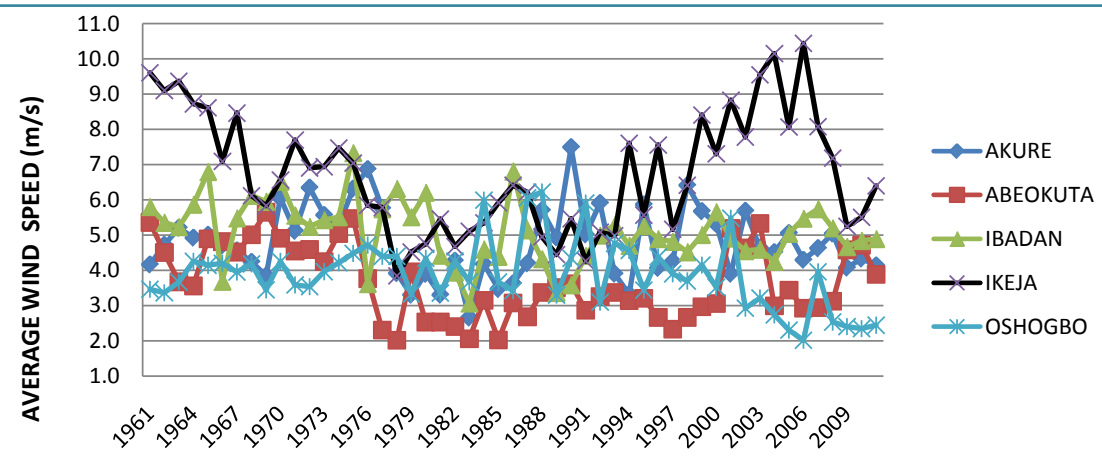

Figure 2. Annual averages wind speeds (at $10 \mathrm{~m}$ height) over Abeokuta, Akure, Ibadan, Ikeja and Oshogbo, Nigeria for the period 1961-2011.

A survey of wind energy potential of all the capital cities of Nigeria [21], obtained a similar result in which Ikeja with a monthly mean wind speed of $3 \mathrm{~m} / \mathrm{s}$, was reported as having the highest potential for electricity generation in the south western Nigeria.

In contrast to wind regimes of south western Nigeria, wind in the northern part of Nigeria has been reported [11] [21] to have better potential for electricity generation. Also [11] [21] reported that winds in the southeastern region of the country have higher potential for electricity generation than those of the southwest.

The frequency of occurrence of the wind speed data are also presented in Table 2 and Figure 3. Clearly, the percentage frequency of wind between 2.0 and $5.9 \mathrm{~m} / \mathrm{s}$ are $62.1 \%$ for Abeokuta $72.2 \%$ for Akure, $71.1 \%$ for Ibadan , $40.5 \%$ for Ikeja and $63.4 \%$ for Oshogbo respectively. Furthermore, the percentage of the annual wind energy above the $3.0 \mathrm{~m} / \mathrm{s}$ cut-in wind speed which contribute to the generation of electricity from wind in most new wind turbine designs are $65.4 \%$ for Abeokuta, $90.2 \%$ for Akure, 93\% for Ibadan, 98.7\% for Ikeja and 70.8\% for Oshogbo respectively. The implication of this is that wind turbines installed at these sites will work for most of the time. This is in agreement with the findings of previous works for the region [1] [11].

The result of a Weibull statistical analysis on the wind speed data is displayed in Tables 3(a)-(e), and the corresponding CDF and PDF plots for the seasons are shown in Figures 7-9. These figures demonstrate that the wind profiles for these periods and whole year data series follow the same cumulative distribution pattern.

Furthermore, the values of $\mathrm{k}$ and $\mathrm{c}$ from the analysis across all the stations ranged between $2.99 \leq \mathrm{k} \leq 5.32$ and $3.02 \leq \mathrm{c} \leq 8.57$, respectively. These high values of $\mathrm{k}$ and $\mathrm{c}(\mathrm{k} \geq 2$ and $\mathrm{c} \geq 2)$ indicate a data spread in a perfectly normal distribution [19], and also show that the data spread exhibits good uniformity with relatively small scatter [22]. The scale parameter, c, further indicates how windy a location under consideration is, whereas the shape parameter, $\mathrm{k}$, indicates how peaked the wind distribution is [20]. Thus, if the wind speeds tends to spike steeply at a certain value, the distribution will have a high $\mathrm{k}$ value.

The Weibull results of standard deviation were compared with the actual standard deviation to assess the degree of convergence. The results are displayed in Figure 4. Figure 5 also show that the Weibull scale parameter "C" and wind speed has a correlation.

Figure 6 clearly demonstrated that all the sites have a better magnitude of wind speed profile in the wet (April to September) than in the dry season (October to March). Ikeja however showed much better wind speed profile in the wet than others and this is due to itslocation which is close to the Atlantic Ocean, thus, the ocean wind blows into the city. The mean measured data distribution between the dry and wet periods gave the range of mean wind speeds as 3.5 to $4.3 \mathrm{~m} / \mathrm{s}$ and 3.5 to $4.1 \mathrm{~m} / \mathrm{s}$ for Abeokuta, 4.3 to $5.3 \mathrm{~m} / \mathrm{s}$ and 4.1 to $5.4 \mathrm{~m} / \mathrm{s}$ for Akure, 5.0 to $6.0 \mathrm{~m} / \mathrm{s}$ and 3.8 to $5.6 \mathrm{~m} / \mathrm{s}$ for Ibadan, 6.4 to $7.7 \mathrm{~m} / \mathrm{s}$ and 5.8 to $7.5 \mathrm{~m} / \mathrm{s}$ for Ikeja, 3.5 to $4.6 \mathrm{~m} / \mathrm{s}$ and 2.7 to $4.7 \mathrm{~m} / \mathrm{s}$ for Oshogbo respectively. Other studies have shown these seasonal signatures of winds in Nigeria [1] [18].

The seasonal and whole year's PDF and CDF plots are presented in Figures 7-9. The figures shows that the wind speed profiles for the periods follow the same cumulative distribution pattern. These patterns were also observed in previous studies [1] [18] [23]. The difference in shapes of the CDF and PDF plots were the results of the varying values of $\mathrm{k}$ and $\mathrm{c}$.

On the wind power density across the period and years considered (Figure 10 and Figure 11), Ikeja has the highest wind power potential with its peak in August and 2006 while Oshogbo has the least. As can be seen in 


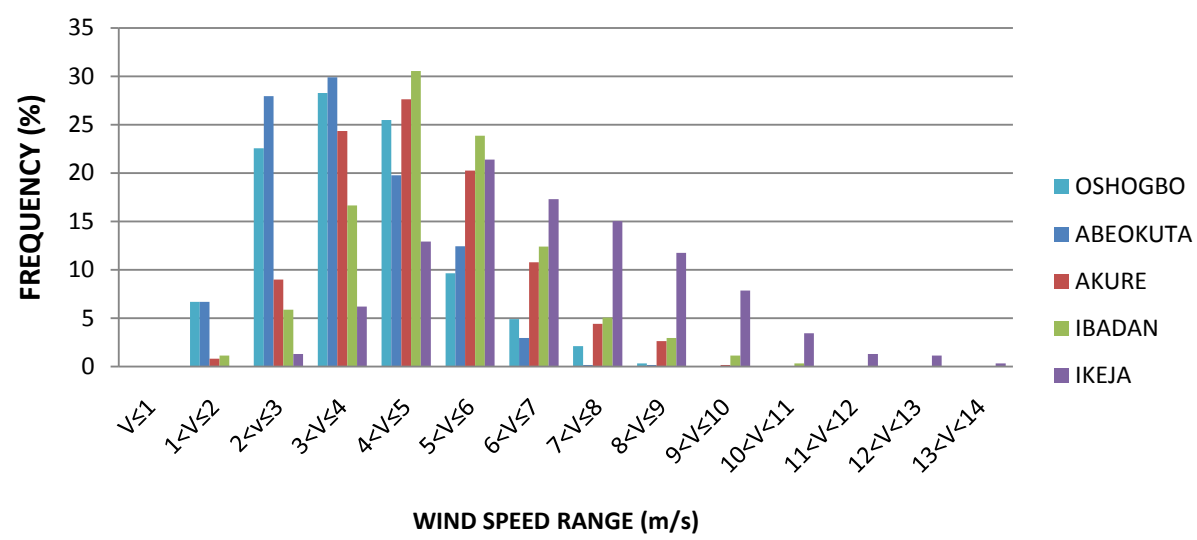

Figure 3. Frequency of wind speed data (10 m height) over Abeokuta, Akure, Ibadan, Ikeja and Oshogbo, Nigeria for the period 1961-2011.

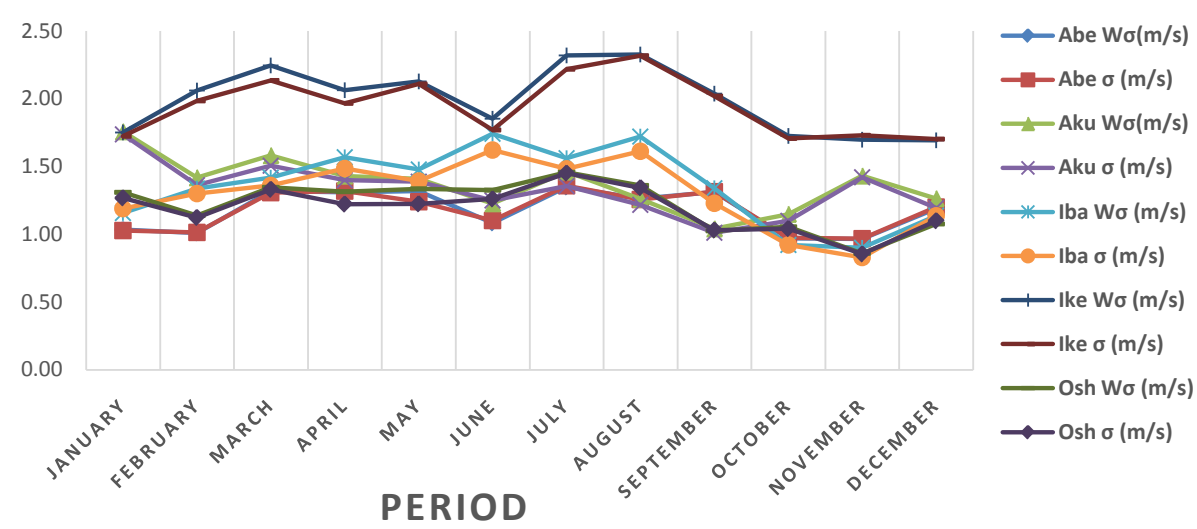

Figure 4. Actual standard deviation and Weibull deviation of wind over Abeokuta, Akure, Ibadan, Ikeja and Oshogbo, Nigeria for the period 1961-2011.

Table 2. Frequency of occurrence of wind speed data over Abeokuta, Akure, Ibadan, Ikeja and Oshogbo, Nigeria for the period 1961-2011.

\begin{tabular}{cccccc}
\hline \multicolumn{5}{c}{ FREQUENCY OF OCCURANCE (\%) } \\
\hline RANGE & ABEOKUTA & AKURE & IBADAN & IKEJA & OSHOGBO \\
\hline $\mathrm{V} \leq 1$ & 0.0 & 0.0 & 0.0 & 0.0 & 0.0 \\
$1<\mathrm{V} \leq 2$ & 6.7 & 0.8 & 1.1 & 0.0 & 6.7 \\
$2<\mathrm{V} \leq 3$ & 28.0 & 9.0 & 5.9 & 1.3 & 22.5 \\
$3<\mathrm{V} \leq 4$ & 29.9 & 24.3 & 16.7 & 6.2 & 28.3 \\
$4<\mathrm{V} \leq 5$ & 19.8 & 27.6 & 30.6 & 12.9 & 25.5 \\
$5<\mathrm{V} \leq 6$ & 12.4 & 20.3 & 23.9 & 21.4 & 9.6 \\
$6<\mathrm{V} \leq 7$ & 2.9 & 10.8 & 12.4 & 17.3 & 4.9 \\
$7<\mathrm{V} \leq 8$ & 0.2 & 4.4 & 5.1 & 15.0 & 2.1 \\
$8<\mathrm{V} \leq 9$ & 0.2 & 2.6 & 2.9 & 11.8 & 0.3 \\
$9<\mathrm{V} \leq 10$ & 0.0 & 0.2 & 1.1 & 7.8 & 0.0 \\
$10<\mathrm{V} \leq 11$ & 0.0 & 0.0 & 0.3 & 3.4 & 0.0 \\
$11<\mathrm{V} \leq 12$ & 0.0 & 0.0 & 0.0 & 1.3 & 0.0 \\
$12<\mathrm{V} \leq 13$ & 0.0 & 0.0 & 0.0 & 1.1 & 0.0 \\
$13<\mathrm{V} \leq 14$ & 0.0 & 0.0 & 0.0 & 0.3 & 0.0 \\
\hline
\end{tabular}


Table 3. Results of the Weibull analysis of wind data for (a) Abeokuta (b) Akure (c) Ibadan (d) Ikeja and (e) Oshogbo, Nigeria.

(a)

\begin{tabular}{ccccccccc}
\hline Period & Vweibull $(\mathbf{m} / \mathbf{s})$ & $\mathbf{c}(\mathbf{m} / \mathbf{s})$ & $\mathbf{k}(-)$ & $\mathbf{f}(\mathbf{v})$ & $\mathbf{F}(\mathbf{V})$ & $\mathbf{p}(\mathbf{v})\left(\mathbf{W} / \mathbf{m}^{2}\right)$ & $\mathbf{V m p}(\mathbf{m} / \mathbf{s})$ & $\mathbf{V e m a x}(\mathbf{m} / \mathbf{s})$ \\
\hline JANUARY & 3.00 & 3.89 & 3.79 & 0.33 & 0.31 & 64.54 & 3.59 & 4.35 \\
FEBRUARY & 3.75 & 4.13 & 4.18 & 0.38 & 0.49 & 74.03 & 3.87 & 4.53 \\
MARCH & 4.11 & 4.57 & 3.45 & 0.29 & 0.50 & 109.65 & 4.14 & 5.22 \\
APRIL & 4.24 & 4.71 & 3.59 & 0.29 & 0.50 & 117.11 & 4.30 & 5.32 \\
MAY & 3.81 & 4.24 & 3.16 & 0.29 & 0.51 & 91.22 & 3.76 & 4.96 \\
JUNE & 3.51 & 3.90 & 3.60 & 0.35 & 0.49 & 66.68 & 3.56 & 4.41 \\
JULY & 3.74 & 4.20 & 3.03 & 0.28 & 0.51 & 89.96 & 3.68 & 4.96 \\
AUGUST & 3.95 & 4.40 & 3.46 & 0.30 & 0.50 & 97.40 & 3.99 & 5.02 \\
SEPTEMBER & 3.76 & 4.21 & 3.15 & 0.29 & 0.50 & 89.21 & 3.73 & 4.92 \\
OCTOBER & 3.45 & 3.82 & 4.00 & 0.40 & 0.49 & 59.54 & 3.55 & 4.22 \\
NOVEMBER & 3.24 & 3.59 & 3.74 & 0.40 & 0.49 & 50.96 & 3.30 & 4.02 \\
DECEMBER & 3.28 & 3.69 & 3.02 & 0.32 & 0.51 & 61.13 & 3.22 & 4.36 \\
DRY SEASON & 3.47 & 3.95 & 3.70 & 0.35 & 0.46 & 69.98 & 3.61 & 4.45 \\
WET SEASON & 3.83 & 4.28 & 3.33 & 0.30 & 0.50 & 91.93 & 3.84 & 4.93 \\
WHOLE YEAR & 3.65 & 4.11 & 3.51 & 0.33 & 0.48 & 80.95 & 3.72 & 4.69 \\
\hline
\end{tabular}

(b)

\begin{tabular}{ccccccccc}
\hline Period & Vweibull $(\mathbf{m} / \mathbf{s})$ & $\mathbf{c}(\mathbf{m} / \mathbf{s})$ & $\mathbf{k}(-)$ & $\mathbf{f}(\mathbf{v})$ & $\mathbf{F}(\mathbf{V})$ & $\mathbf{p}(\mathbf{v})\left(\mathbf{W} / \mathbf{m}^{2}\right)$ & $\mathbf{V m p}(\mathbf{m} / \mathbf{s})$ & Vemax $(\mathbf{m} / \mathbf{s})$ \\
\hline JANUARY & 5.22 & 5.83 & 3.27 & 0.22 & 0.50 & 232.20 & 5.21 & 6.74 \\
FEBRUARY & 4.97 & 5.49 & 3.92 & 0.27 & 0.49 & 178.43 & 5.09 & 6.09 \\
MARCH & 5.40 & 5.97 & 3.81 & 0.24 & 0.50 & 233.08 & 5.51 & 6.67 \\
APRIL & 5.27 & 5.80 & 4.15 & 0.27 & 0.49 & 206.36 & 5.43 & 6.38 \\
MAY & 4.96 & 5.47 & 3.94 & 0.27 & 0.49 & 176.94 & 5.08 & 6.07 \\
JUNE & 4.85 & 5.32 & 4.49 & 0.32 & 0.48 & 154.08 & 5.03 & 5.78 \\
JULY & 5.23 & 5.75 & 4.00 & 0.26 & 0.50 & 203.67 & 5.35 & 6.36 \\
AUGUST & 4.86 & 5.33 & 4.35 & 0.31 & 0.49 & 156.33 & 5.02 & 5.81 \\
SEPTEMBER & 4.35 & 4.74 & 4.75 & 0.37 & 0.49 & 106.69 & 4.51 & 5.11 \\
OCTOBER & 4.02 & 4.44 & 3.91 & 0.34 & 0.49 & 94.51 & 4.11 & 4.93 \\
NOVEMBER & 4.16 & 4.65 & 3.19 & 0.27 & 0.50 & 119.46 & 4.13 & 5.42 \\
DECEMBER & 4.14 & 4.58 & 3.63 & 0.30 & 0.50 & 107.40 & 4.19 & 5.17 \\
DRY SEASON & 4.65 & 5.16 & 3.62 & 0.27 & 0.50 & 160.85 & 4.71 & 5.84 \\
WET SEASON & 4.92 & 5.40 & 4.28 & 0.30 & 0.49 & 167.34 & 5.07 & 5.92 \\
WHOLE YEAR & 4.79 & 5.28 & 3.95 & 0.29 & 0.49 & 164.10 & 4.89 & 5.88 \\
\hline
\end{tabular}


(c)

\begin{tabular}{ccccccccc} 
Period & Vweibull (m/s) & $\mathbf{c}(\mathbf{m} / \mathbf{s})$ & $\mathbf{k}(-)$ & $\mathbf{f}(\mathbf{v})$ & $\mathbf{F}(\mathbf{V})$ & $\mathbf{p}(\mathbf{v})\left(\mathbf{W} / \mathbf{m}^{2}\right)$ & $\mathbf{V m p}(\mathbf{m} / \mathbf{s})$ & $\mathbf{V e m a x}(\mathbf{m} / \mathbf{s})$ \\
\hline JANUARY & 4.29 & 4.73 & 4.18 & 0.33 & 0.49 & 111.36 & 4.43 & 5.19 \\
FEBRUARY & 5.04 & 5.53 & 4.24 & 0.29 & 0.49 & 177.12 & 5.19 & 6.06 \\
MARCH & 5.63 & 6.15 & 4.49 & 0.27 & 0.49 & 237.50 & 5.81 & 6.67 \\
APRIL & 5.97 & 6.54 & 4.29 & 0.25 & 0.49 & 291.39 & 6.15 & 7.15 \\
MAY & 5.39 & 5.92 & 4.09 & 0.26 & 0.49 & 220.65 & 5.53 & 6.53 \\
JUNE & 5.58 & 6.18 & 3.54 & 0.22 & 0.50 & 266.44 & 5.62 & 7.01 \\
JULY & 5.79 & 6.36 & 4.17 & 0.25 & 0.49 & 270.91 & 5.96 & 6.99 \\
AUGUST & 5.83 & 6.43 & 3.77 & 0.22 & 0.50 & 292.81 & 5.93 & 7.20 \\
SEPTEMBER & 5.02 & 5.50 & 4.21 & 0.29 & 0.49 & 174.37 & 5.15 & 6.03 \\
OCTOBER & 4.27 & 4.63 & 5.32 & 0.42 & 0.48 & 95.01 & 4.45 & 4.92 \\
NOVEMBER & 3.85 & 4.17 & 4.85 & 0.43 & 0.49 & 72.12 & 3.98 & 4.48 \\
DECEMBER & 4.14 & 4.56 & 4.09 & 0.34 & 0.49 & 100.66 & 4.26 & 5.03 \\
DRY SEASON & 4.54 & 4.96 & 4.53 & 0.35 & 0.49 & 132.30 & 4.69 & 5.39 \\
WET SEASON & 5.59 & 6.16 & 4.01 & 0.25 & 0.49 & 252.76 & 5.72 & 6.82 \\
WHOLE YEAR & 5.07 & 5.56 & 4.27 & 0.30 & 0.49 & 192.53 & 5.21 & 6.10 \\
\hline
\end{tabular}

(d)

\begin{tabular}{ccccccccc}
\hline Period & Vweibull $(\mathbf{m} / \mathbf{s})$ & $\mathbf{c}(\mathbf{m} / \mathbf{s})$ & $\mathbf{k}(-)$ & $\mathbf{f}(\mathbf{v})$ & $\mathbf{F}(\mathbf{V})$ & $\mathbf{p}(\mathbf{v})\left(\mathbf{W} / \mathbf{m}^{2}\right)$ & $\mathbf{V m p}(\mathbf{m} / \mathbf{s})$ & $\mathbf{V e m a x}(\mathbf{m} / \mathbf{s})$ \\
\hline JANUARY & 6.45 & 7.10 & 4.14 & 0.22 & 0.49 & 377.22 & 6.64 & 7.80 \\
FEBRUARY & 7.29 & 8.04 & 3.97 & 0.19 & 0.49 & 559.02 & 7.47 & 8.91 \\
MARCH & 7.47 & 8.27 & 3.70 & 0.17 & 0.50 & 626.32 & 7.59 & 9.29 \\
APRIL & 7.08 & 7.82 & 3.83 & 0.19 & 0.49 & 522.03 & 7.22 & 8.73 \\
MAY & 6.36 & 7.10 & 3.30 & 0.18 & 0.50 & 418.47 & 6.36 & 8.20 \\
JUNE & 6.40 & 7.06 & 3.86 & 0.21 & 0.50 & 383.90 & 6.54 & 7.87 \\
JULY & 7.27 & 8.07 & 3.46 & 0.17 & 0.50 & 600.38 & 7.31 & 9.20 \\
AUGUST & 7.72 & 8.57 & 3.70 & 0.17 & 0.49 & 698.06 & 7.87 & 9.63 \\
SEPTEMBER & 6.81 & 7.55 & 3.73 & 0.19 & 0.49 & 475.66 & 6.94 & 8.47 \\
OCTOBER & 6.40 & 7.04 & 4.18 & 0.22 & 0.49 & 367.86 & 6.60 & 7.74 \\
NOVEMBER & 5.85 & 6.48 & 3.86 & 0.23 & 0.49 & 296.46 & 6.00 & 7.22 \\
DECEMBER & 5.85 & 6.47 & 3.87 & 0.23 & 0.49 & 294.83 & 5.99 & 7.21 \\
DRY SEASON & 6.55 & 7.23 & 3.95 & 0.21 & 0.49 & 420.28 & 6.71 & 8.03 \\
WET SEASON & 6.94 & 7.70 & 3.65 & 0.18 & 0.50 & 516.42 & 7.04 & 8.68 \\
WHOLE YEAR & 6.74 & 7.46 & 3.80 & 0.20 & 0.49 & 468.35 & 6.88 & 8.36 \\
\hline
\end{tabular}


(e)

\begin{tabular}{ccccccccc}
\hline Period & Vweibull $(\mathbf{m} / \mathbf{s})$ & $\mathbf{c}(\mathbf{m} / \mathbf{s})$ & $\mathbf{k}(-)$ & $\mathbf{f}(\mathbf{v})$ & $\mathbf{F}(\mathbf{V})$ & $\mathbf{p}(\mathbf{v}) \mathbf{( W / \mathbf { m } ^ { 2 } )}$ & $\mathbf{V m p}(\mathbf{m} / \mathbf{s})$ & $\mathbf{V e m a x}(\mathbf{m} / \mathbf{s})$ \\
\hline JANUARY & 3.60 & 4.03 & 2.99 & 0.29 & 0.51 & 80.27 & 3.52 & 4.78 \\
FEBRUARY & 4.06 & 4.48 & 4.00 & 0.34 & 0.49 & 96.68 & 4.17 & 4.96 \\
MARCH & 4.75 & 5.24 & 3.94 & 0.29 & 0.49 & 155.14 & 4.86 & 5.81 \\
APRIL & 4.52 & 4.98 & 3.82 & 0.29 & 0.50 & 134.90 & 4.60 & 5.56 \\
MAY & 3.99 & 4.43 & 3.27 & 0.29 & 0.51 & 102.39 & 3.97 & 5.13 \\
JUNE & 4.03 & 4.47 & 3.34 & 0.29 & 0.51 & 104.21 & 4.02 & 5.15 \\
JULY & 4.56 & 5.07 & 3.46 & 0.26 & 0.50 & 149.20 & 4.60 & 5.79 \\
AUGUST & 4.40 & 4.89 & 3.60 & 0.28 & 0.50 & 131.40 & 4.47 & 5.53 \\
SEPTEMBER & 3.54 & 3.91 & 3.85 & 0.37 & 0.49 & 65.25 & 3.62 & 4.36 \\
OCTOBER & 3.22 & 3.60 & 3.37 & 0.36 & 0.50 & 53.84 & 3.24 & 4.13 \\
NOVEMBER & 2.72 & 3.02 & 3.51 & 0.45 & 0.50 & 31.46 & 2.75 & 3.44 \\
DECEMBER & 3.20 & 3.58 & 3.28 & 0.36 & 0.50 & 53.73 & 3.20 & 4.14 \\
DRY SEASON & 3.59 & 3.99 & 3.52 & 0.35 & 0.50 & 78.52 & 3.62 & 4.54 \\
WET SEASON & 4.17 & 4.63 & 3.56 & 0.30 & 0.50 & 114.56 & 4.21 & 5.25 \\
WHOLE YEAR & 3.88 & 4.31 & 3.54 & 0.32 & 0.50 & 96.54 & 3.92 & 4.90 \\
\hline
\end{tabular}

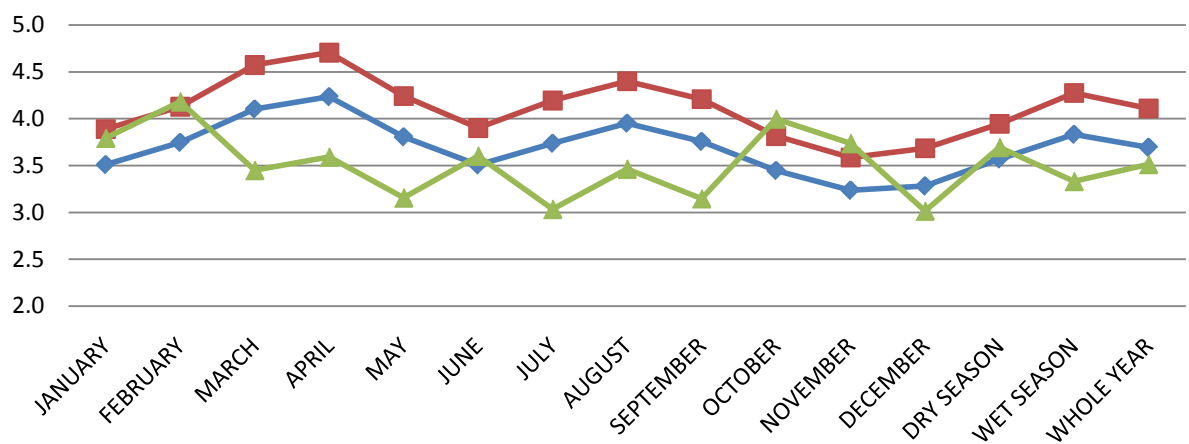

$\neg$ Weibull average wind speed - Weibull scale parameter 'c' $\rightarrow$ Weibull shape parameter 'k'

Figure 5. Plot of Weibull parameters and wind speed.

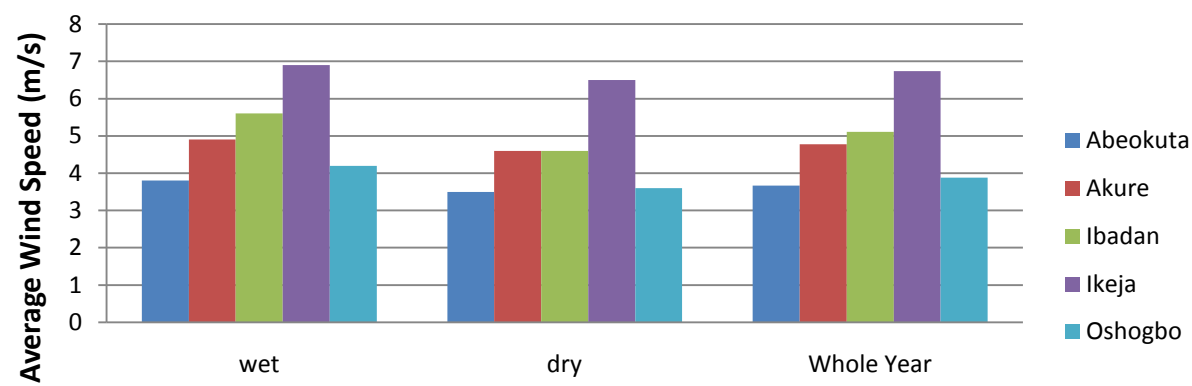

Period

Figure 6. Seasonal and whole year (1961-2011) variation of average wind speed values over Abeokuta, Akure, Ibadan, Ikeja and Oshogbo, Nigeria. 


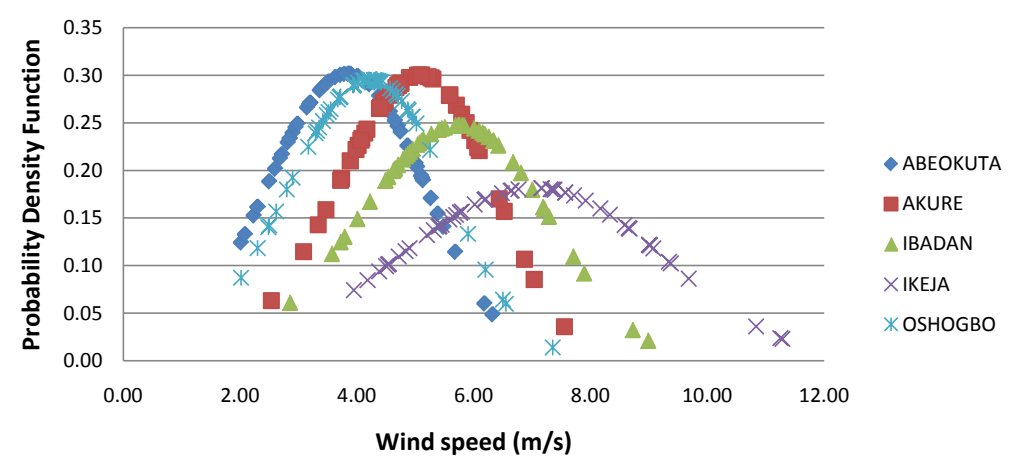

(a)

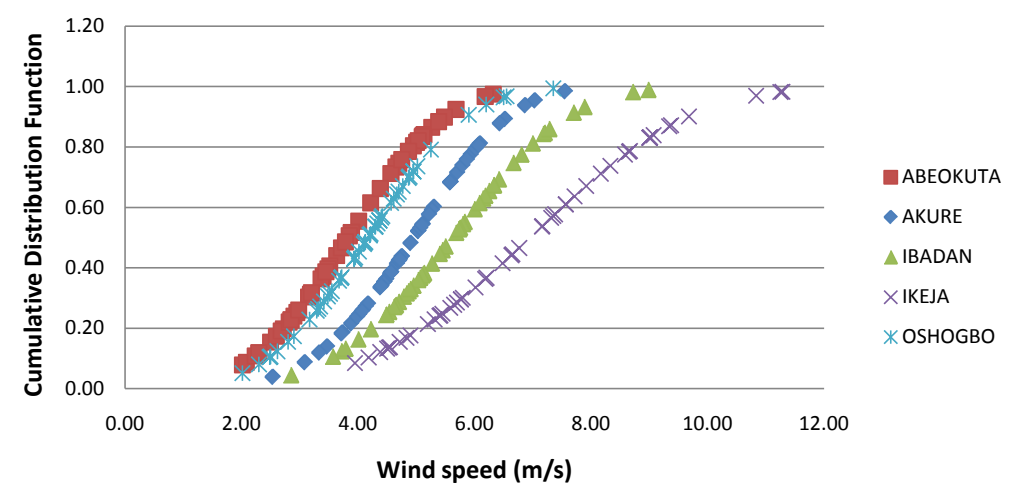

(b)

Figure 7. Wet season Probability Density Function (PDF) and Cumulative Distribution Function (CDF) from the Weibull analysis for Abeokuta, Akure, Ibadan, Ikeja and Oshogbo, Nigeria.

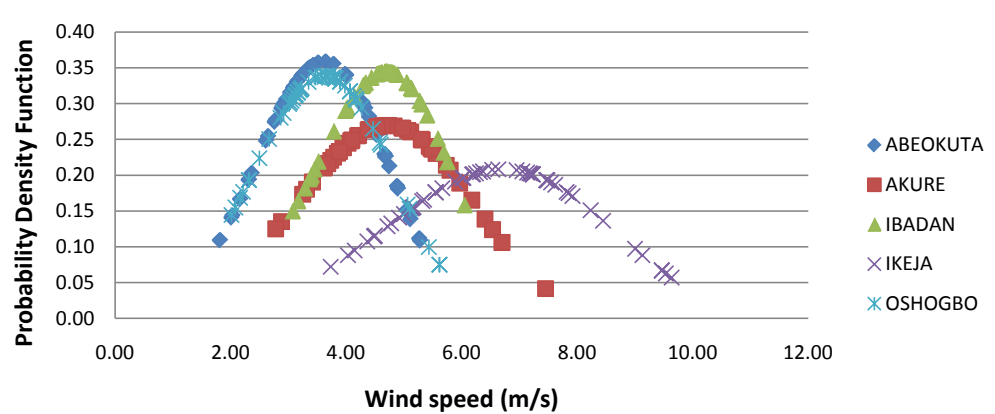

(a)

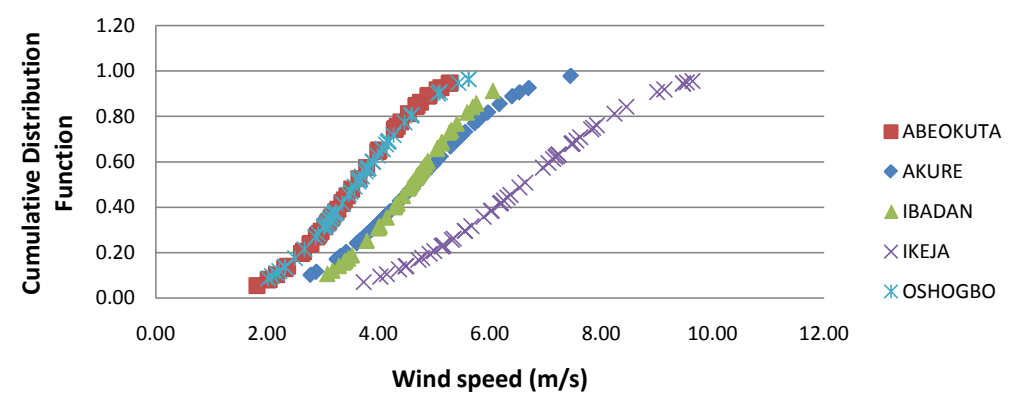

(b)

Figure 8. Dry season Probability Density Function (PDF) and Cumulative Distribution Function (CDF) from the Weibull analysis for Abeokuta, Akure, Ibadan, Ikeja and Oshogbo, Nigeria. 


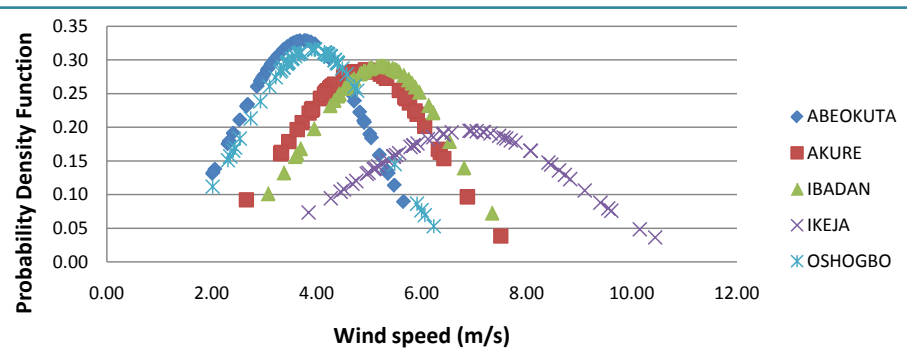

(a)

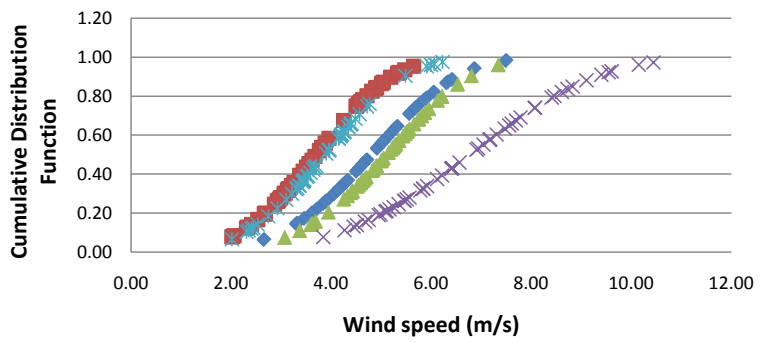

ABEOKUTA

$\triangle$ AKURE

$\triangle$ IBADAN

$\times$ IKEJA

OSHOGBO

(b)

Figure 9. Whole year (1961-2011) Probability Density Function (PDF) and Cumulative Distribution Function (CDF) from the Weibull analysis for Abeokuta, Akure, Ibadan, Ikeja and Oshogbo, Nigeria.

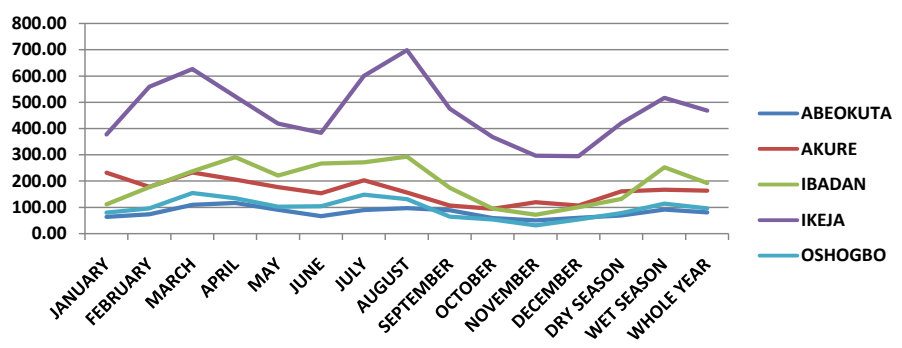

Figure 10. Monthly and seasonal wind power density $\left(\mathrm{W} / \mathrm{m}^{2}\right)$.

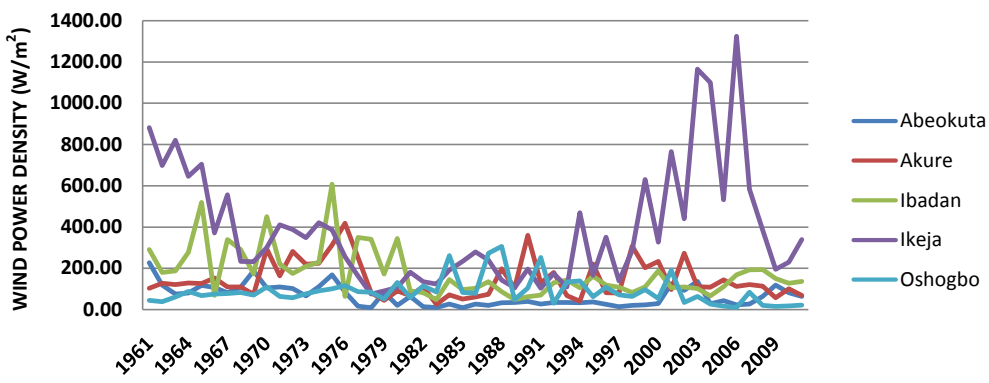

Figure 11. Annual wind power density over Abeokuta, Akure, Ibadan, Ikeja and Oshogbo, Nigeria.

Figure 11, the significant monthly change in power density according to Keyhani et al. [20] underscores the importance of distinguishing different months and periods of the year when a wind power project is assessed or designed to produce maximum power.

Wind power density directly determines electric power efficiency in using wind energy in the sense that the higher the density, the higher the electric power generating potential of the area. Thus the potential for production of electric power during this period will be much greater in Ikeja than in other sites.

The monthly and seasonal most probable $\left(v_{m p}\right)$ and maximum energy carrying wind speeds $\left(v_{E \max }\right)$ analyses for all the sites are given by Figures 12(a)-(e). The values of $v_{m p}$ ranged from 2.75 to $7.87 \mathrm{~m} / \mathrm{s}$ (for January 


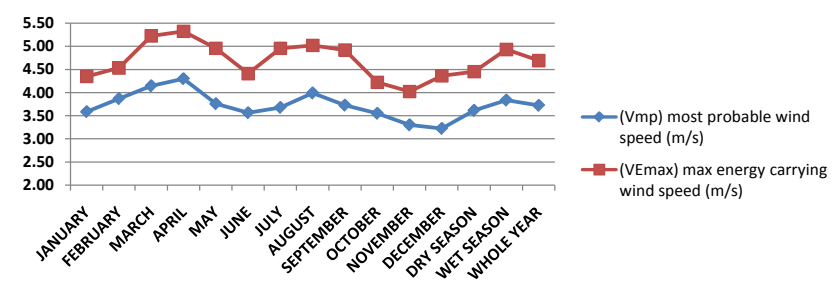

(a)

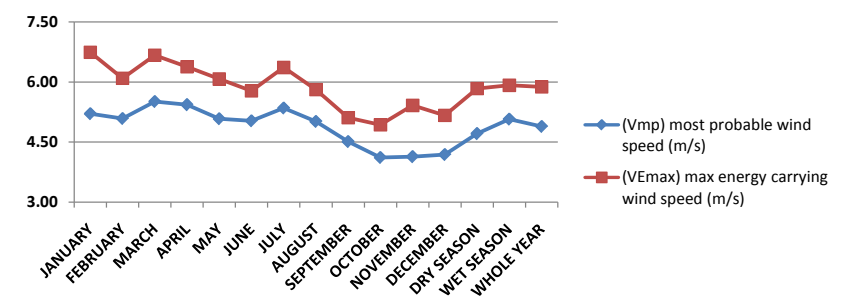

(b)

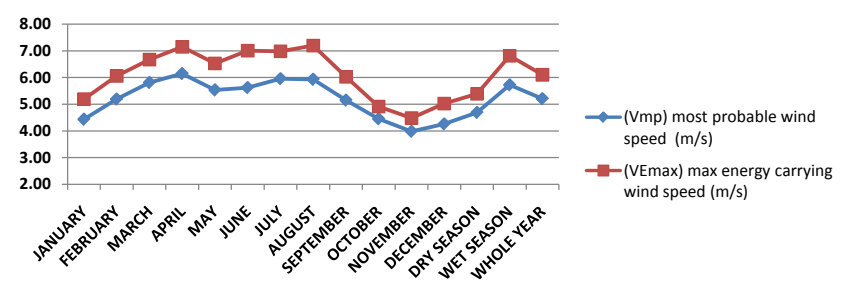

(c)

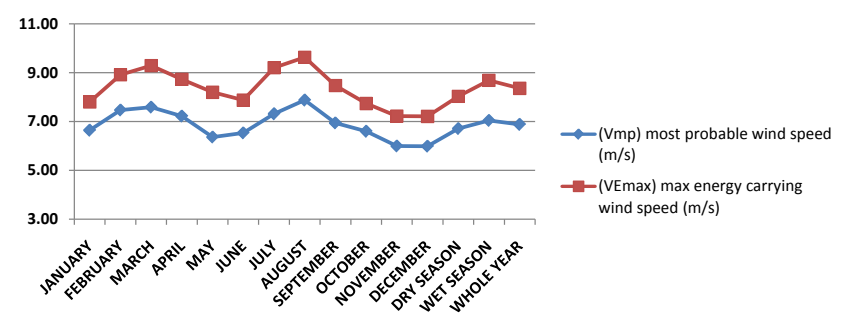

(d)

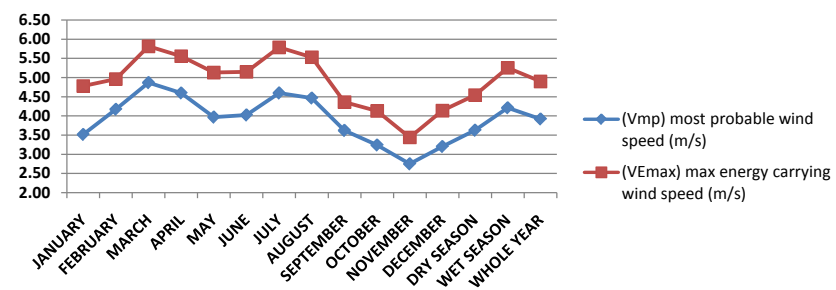

(e)

Figure 12. The most probable $\left(v_{m p}\right)$ and maximum energy carrying wind speed $\left(v_{E \max }\right)$ over (a) Abeokuta; (b) Akure; (c) Ibadan; (d) Ikeja; and (e) Oshogbo for the period 1961-2011.

to December), 3.61 to $6.71 \mathrm{~m} / \mathrm{s}$ (dry season), 3.84 to $7.04 \mathrm{~m} / \mathrm{s}$ (wet season), and 3.92 to $6.88 \mathrm{~m} / \mathrm{s}$ (whole years). For the yearly analysis, it ranged from 2.46 to $10.98 \mathrm{~m} / \mathrm{s}$. Also, the values of $v_{E \max }$ ranged from 3.44 to 9.63 m/s (for January to December), 4.45 to $8.03 \mathrm{~m} / \mathrm{s}$ (dry season), 4.93 to $8.68 \mathrm{~m} / \mathrm{s}$ (wet season), and 4.69 to 8.36 $\mathrm{m} / \mathrm{s}$ (whole years). For the yearly data, it ranged from 2.26 to $11.85 \mathrm{~m} / \mathrm{s}$ (1961 to 2011), respectively.

The most probable wind speed corresponds to the peak of the probability density function, while the wind speed carrying maximum energy can be used to estimate the wind turbine design or rated wind speed. Prior studies have shown that wind turbine system operates most efficiently at its rated wind speed. Therefore, it is required that the 
rated wind speed and the wind speed carrying maximum energy should be as close as possible [24].

\section{Conclusions}

In this study, the assessment of the potential of wind power generation at five selected locations in the southwestern part of Nigeria was carried out. Fifty-one years of monthly mean wind data at 10-m height from the Nigeria meteorological department Oshodi, Nigeria were assessed and subjected to Weibull two-parameter and other analyses. It was discovered that:

1) The annual mean wind speeds for Abeokuta, Akure, Ibadan, Ikeja and Oshogbo are 3.67, 4.79, 5.11, 6.74 and $3.88 \mathrm{~m} / \mathrm{s}$, respectively. The annual values of the wind speed carrying maximum energy for these locations are respectively 6.48, 4.33 and $3.90 \mathrm{~m} / \mathrm{s}$.

2) The mean annual value of Weibull shape parameter $k$ is between 5.36 and 8.34 , while the annual value of scale parameter $c$ is between 3.93 and $7.21 \mathrm{~m} / \mathrm{s}$. The two-parameter Weibull probability distribution was adequate in predicting the mean wind speed distribution in all the five sites.

3) The annual mean power densities for Abeokuta, Akure, Ibadan, Ikeja and Oshogbo are 65.09, 145.07, 176.96, 387.07 and $87.34 \mathrm{~W} / \mathrm{m}^{2}$ respectively. Both the mean wind speed and power density are generally used to classify the wind energy resource (e.g., Pacific Northwest Laboratory (PNL) wind power classification scheme, Illica et al. [25]). Therefore, based on the wind data used in this study, the wind energy resource in south-west Nigeria may generally be classified into class 1 . However, based on monthly mean power density, the wind resource may fall into higher class category in some cases.

\section{References}

[1] Ajayi, O.O., Fagbenle, R.O. and Katende, J. (2011) Assessment of Wind Power Potential and Wind Electricity Generation Using WECS of Two Sites in South West, Nigeria. International Journal of Energy Science, 1, 78-92.

[2] Oztopal, A. Sahin, A.D. Akgun, N. and Sen, Z. (2000) On the Regional Wind Energy Potential of Turkey. Energy, 25, 189-200. http://dx.doi.org/10.1016/S0360-5442(99)00060-2

[3] Feretić, D., Tomšić, Z. and Čavlina, N., (1999) Feasibility Analysis of Wind-Energy Utilization in Croatia. Energy, 24, 239-246. http://dx.doi.org/10.1016/S0360-5442(98)00088-7

[4] Sulaiman, M.Y., Akaak, A.M., Abd. Wahab, M., Zakaria, A., Sulaiman, Z.A. and Suradi, J. (2002) Wind Characteristic of Oman. Energy, 27, 35-46. http://dx.doi.org/10.1016/S0360-5442(01)00055-X

[5] Rehman, S. and Ahmed, A. (2005) Assessment of Wind Energy Potential for Coastal Locations of the Kingdom of Saudi Arabia. Energy, 29, 1105-1115. http://dx.doi.org/10.1016/j.energy.2004.02.026

[6] Akpinar, E.K. and Akpinar, S. (2005) An Assessment on Seasonal Analysis of Wind Energy Characteristics and Wind Turbine Characteristics. Energy Conversion and Management, 46, 1848-1867. http://dx.doi.org/10.1016/j.enconman.2004.08.012

[7] Ahmed Shata, A.S. and Hanitsch, R. (2006) Evaluation of Wind Energy Potential and Electricity Generation on the Coast of Mediterranean Sea in Egypt. Renewable Energy, 31, 1183-1202. http://dx.doi.org/10.1016/j.renene.2005.06.015

[8] Ahmed, S.A. (2010) Wind Energy as a Potential Generation Source at Ras Benas, Egypt. Renewable and Sustainable Energy Reviews, 14, 2167-217. http://dx.doi.org/10.1016/j.rser.2010.03.006

[9] Albadi, M.H., El-Saadany, E.F. and Albadi, H.A. (2009) Wind to Power a New City in Oman. Energy, 34, $1579-1586$. http://dx.doi.org/10.1016/j.energy.2009.07.003

[10] Ojosu, J.O. and Salawu, R.I. (1990) A Survey of Wind Energy Potential in Nigeria. Solar and Wind Technology, 7, 155-167.

[11] Ojosu, J.O. and Salawu, R.I. (1990) An Evaluation of Wind Energy Potential as a Power Generation Source in Nigeria. Solar and Wind Technology, 7, 663-673. http://dx.doi.org/10.1016/0741-983X(90)90041-Y

[12] Adekoya, L.O. and Adewale, A.A. (1992) Wind Energy Potential of Nigeria. Renewable Energy, 2, 35-39. http://dx.doi.org/10.1016/0960-1481(92)90057-A

[13] Fagbenle, R.O. and Karayiannis, T.G. (1994) On the Wind Energy Resources of Nigeria. International Journal of Energy Research, 18, 493-508. http://dx.doi.org/10.1002/er.4440180502

[14] Energy Commission of Nigeria and United Nations Development Programme (ECN-UNDP) (2005).

[15] Energy Commission of Nigeria and United Nations Development Programme (ECN-UNDP) (2005) Renewable Energy Master Plan: Final Draft Report. http://www.iceednigeria.org/workspace/uploads/nov.-2005.pdf 
[16] Asiegbu, A.D. and Iwuoha, G.S. (2007) Studies of Wind Resources in Umudike, South East Nigeria-An Assessment of Economic Viability. Journal of Engineering and Applied Sciences, 2, 1539-1541.

[17] Fadare, D.A.A. (2008) Statistical Analysis of Wind Energy Potential in Ibadan, Nigeria, Based on Weibull Distribution Function. The Pacific Journal of Science and Technology, 9, 110-119.

[18] Fagbenle, R.O., Katende, J., Ajayi, O.O. and Okeniyi, J.O. (2011) Assessment of Wind Energy Potential of Two Sites in North-East, Nigeria. Renewable Energy, 36, 1277-1283. http://dx.doi.org/10.1016/j.renene.2010.10.003

[19] Carta, J.A., Ramírez, P. and Velázquez, S. (2009) A Review of Wind Speed Probability Distributions Used in Wind Energy Analysis: Case Studies in the Canary Islands. Renewable and Sustainable Energy Reviews, 13, 933-955. http://dx.doi.org/10.1016/j.rser.2008.05.005

[20] Keyhani, A., Ghasemi-Varnamkhasti, M., Khanali, M. and Abbaszadeh, R. (2010) An Assessment of Wind Energy Potential as a Power Generation Source in the Capital of Iran, Tehran. Energy, 35, 188-201. http://dx.doi.org/10.1016/j.energy.2009.09.009

[21] Chineke, C.T. (2009) Boosting Electricity Supply in Nigeria: Wind Energy to the Rescue? Pacific Journal of Science and Technology, 10, 553-560.

[22] Lipson, C. and Sheth, N.J. (1973) Statistical Design and Analysis of Engineering Experiments. McGraw-Hill, New York.

[23] Argungu, G.M., Bala, E.J., Momoh, M., Musa, M., Dabai, K.A., Zangina, U. and Maiyama, B.A. (2013) Statistical Analysis of Wind Energy Resource Potentials For Power Generation In Jos, Nigeria, Based on Weibull Distribution Function. The International Journal Of Engineering And Science (IJES), 2, 22-31.

[24] Mathew, S., Pandey, K.P. and Kumar, A.V. (2002) Analysis of Wind Regimes for Energy Estimation. Renewable Energy, 25, 381-399. http://dx.doi.org/10.1016/S0960-1481(01)00063-5

[25] Ilinca, A., McCarthy, E., Chaumel, J.-L. and Retiveau, J.-L. (2003) Wind Potential Assessment of Quebec Province. Renewable Energy, 28, 1881-1897. http://dx.doi.org/10.1016/S0960-1481(03)00072-7

\section{Nomenclature}

$c(\mathrm{~m} / \mathrm{s})$ : The Weibull scale parameter $f(v)$ : Cumulative distribution function $F(v)$ : Probability distribution function $k$ : Weibull shape parameter or factor $p(v)$ : Wind Power density $\left(\mathrm{W} / \mathrm{m}^{2}\right)$ $v$ : Wind speed $(\mathrm{m} / \mathrm{s})$

$v_{m}$ : Mean wind speed $(\mathrm{m} / \mathrm{s})$

$v_{m p}$ : Most probable wind speed

$v_{\text {Emax }}$ : Wind speed carrying Max Energy

\section{Greek symbols}

$\sigma:$ Standard deviation

$\Gamma(x)$ : The gamma function of $x$

$\rho$ : Air density $\left(\mathrm{kg} / \mathrm{m}^{3}\right)$ 